\title{
Processing of Banana Blossom and its Application in Food Product
}

\author{
P. Fathima Zehla*, D. Vijayalakshmi, V.C. Suvarna and Shilpa Yatnatti \\ Department of Food Science and Nutrition, UAS, GKVK, Bengaluru-560065, India \\ *Corresponding author
}

\begin{abstract}
A B S T R A C T
Keywords

Banana blossom, Nendran, BBP laddu, Sensory score, Nutrient analysis, Microbial population, Storage period

Article Info

Accepted:

08 July 2018

Available Online:

10 August 2018

Banana is a climacteric fruit, during post-harvest handling and commercialization, huge quantities of this fruit is lost. Majority of harvested fruit is thus wasted when it reaches central collection station because of less appealing characteristics. Hence, as a solution to minimize this issue, nutrient-rich product was formulated from major underutilized byproducts of banana, i.e., blossom. Banana blossom of Nendran variety was procured from the local market, processed and made into powder. Banana Blossom Powder (BBP) was incorporated in laddu at various concentrations. Mean sensory scores indicated BBP laddu with 35 per cent blossom powder was best accepted with overall acceptability score of 8.42. The best accepted BBP laddu was analysed for nutrient content. The result revealed BBP laddu was rich in potassium $(410.37 \mathrm{mg}$ ), good source of energy, protein, fat, fibre and fair source of calcium, iron, sodium, vitamin $C$ and $\beta$ - carotene. Microbial population during the storage period of 40 days was evaluated. Total bacterial population of best accepted laddu during $40^{\text {th }}$ day was $1.3 \times 10^{3} \mathrm{cfu} / \mathrm{g}$ and the mold population was 2.2 $\mathrm{x} 10^{2} \mathrm{cfu} / \mathrm{g}$. Cost of the product was less than that of the product available in the market with extended nutrient content.
\end{abstract}

\section{Introduction}

Banana is one of the easily available, low cost and nutrient-rich fruits consumed across the globe. The name came from an Arabic word "banan", means finger. It belongs to kingdom Plantae, family Musaceae and genus Musa. Banana is a staple food for human since time immemorial. Banana is mostly grown in tropical and sub-tropical areas around the world. The fruit can either be consumed as ripe, since it contains high sugar content, or used unripe, mainly in some traditional dishes which demands high starch content. Banana is consumed mainly when they are ripe in
Mexico and some Latin American countries (Rodriguez-Ambriz et al., 2008).

Banana has got immense nutritional and nutraceutical value. It is rich in nutrients and more easily digestible than many other fruit crops with its good aroma, texture and easy to eat property, make it favorite among all. The flower of banana called, banana blossom is consumed as a vegetable in some countries, mainly in India and Malaysia.

The nectar juice obtained from flower buds has got medicinal value, for curing stomach disorders and ulcers (Mohapatra et al., 
2010).The major byproduct of banana, blossom is good source of many nutrients. Along with the fruit wastage, there is an immense wastage of this by-product also. These are usually discarded in water bodies, leading to increased biological oxygen demand (BOD) and thus disturbing aquatic life.

So, need of the day is conversion of agricultural wastes, rich in nutrients but less utilized by human beings and are discarded causing environmental pollution, to value added products which will be liked by all age groups. Hence, as a solution to minimize this issue, nutrient-rich product was formulated from major underutilized byproduct of banana, banana blossom.

\section{Materials and Methods}

Processing of banana blossom (Singh, 2017)

In order to minimize darkening due to enzymatic browning, the uniformly sliced blossom was immersed in various concentrations of citric acid and salt solution for varied time interval. The pre- treated banana blossom sample was dried for 4 hours at $50^{\circ} \mathrm{C}$ Dried blossom sample was then ground into fine powder and used for further studies.

\section{Formulation of product}

Banana Blossom Powder (BBP) laddu was prepared by incorporating $\mathrm{BBP}$ at various concentrations like 35,50 and 65 per cent.

\section{Sensory evaluation}

A 9-point hedonic scale (Avantina, 2006) was used for organoleptic evaluation. The product was evaluated for appearance, texture, colour, aroma/flavour, taste and overall acceptability by 21 semi trained panel members.
Nutrient analysis of the best accepted product

Nutrient analysis of the developed product for moisture, ash, protein, fat, crude fibre calcium was done using AOAC (1980) methods.

Estimation of minerals like iron, sodium and potassium were done by using AAS (Atomic Absorption Spectrophotometer) method. Estimation of $\beta$-carotene and vitamin $C$ was done as per method quoted by Ranganna (1996).

\section{Shelf life study of the best accepted product (Tate, 1995)}

Best-accepted product was packed in 300 gauge LDPE (low-density polyethylene) pouches to conduct storage study.

The microbial analysis of the best-accepted product was carried out by standard plate count method using Nutrient Agar for total bacteria and Martin's Rose Bengal Agar for molds.

\section{Statistical analysis}

Statistical analysis was done using Complete Randomised Design and one-way analysis of the variance. Significance was noted at 5 per cent level.

\section{Cost estimation of the best-accepted product}

Cost of the best-accepted product was calculated by considering cost of the raw material purchased from the market, 30 per cent overhead costs which include labor charge, electricity, machinery, packaging cost, etc. and 15 per of profit was added to the production cost, then the total price was calculated for $100 \mathrm{~g}$ of the product. 


\section{Results and Discussion}

\section{Formulation of product}

Banana Blossom Powder (BBP) laddu was prepared by incorporating BBP at various concentrations like 35, 50 and 65 per cent. The control was devoid of Banana Blossom Powder. The preparation of BBP laddu is depicted in Figure 1.

\section{Sensory evaluation}

Sensory evaluation scores of the BBP laddu are shown in Figure 2. Control had higher scores than the variations. The variation with 35 per cent of banana blossom powder showed higher values for all sensory attributes viz., appearance (7.90), texture (7.47), color (8.61), aroma (8.57), taste (8.52) and overall acceptability (8.42) as compared to other variations viz., 50 and 65 per cent level powder incorporated laddu. Sensory scores for taste and overall acceptability revealed that control was best accepted (8.81, $8.57)$ followed by 35 per cent variation ( 8.52 , $8.42), 50$ per cent variation $(8.19,7.42)$ and the least score was obtained by variation with 65 per cent level banana blossom powder $(6.28,6.42)$ as the taste, appearance and texture was not liked by panel members. A statistically significant decrease in the overall acceptability score was observed at 65 per cent level of incorporation.

Sharmila and Puraikalan (2015) developed dark chocolate by incorporating banana blossom powder. The overall acceptability and rating scale score was higher for the 20 per cent level of incorporation of banana blossom flour. BBP laddu was acceptable at a higher level of incorporation (35\%), which may be due to the difference in the ingredients used for both the product. Ghee and sugar in BBP might be the triggering factors for increased acceptance.
Yenagi et al., (2010) formulated besan laddu with addition of foxtail millet with mean overall acceptability score of 7.6, taste (7.7), appearance and colour (7.6), texture (7.7) and aroma (7.3). Acceptability of the product decreased as the level of incorporation of flour increased.

\section{Nutrient analysis of the best accepted product}

Nutrient content of BBP laddu and control is represented in Table 1. The nutrient content of 35 per cent BBP laddu for protein, fat, carbohydrates, energy and crude fibre was $12.68 \mathrm{~g}, 11.84 \mathrm{~g}, 64 \mathrm{~g}, 413.00 \mathrm{kcal}$ and $6.66 \mathrm{~g}$ respectively. Moisture and ash content was higher for the 35 per cent BBP incorporated laddu $(7.20 \%$ and $4.25 \mathrm{~g})$ than control sample (4.40\% and $0.72 \mathrm{~g})$. Control laddu had more energy as compared to 35 per cent BBP incorporated laddu viz., $423.00 \mathrm{kcal}$ and $413.00 \mathrm{kcal}$ respectively The mineral values of 35 per cent BBP incorporated laddu were higher than control sample. Mineral composition of 35 per cent BBP incorporated laddu for calcium $(38.62 \mathrm{mg})$, iron (11.63mg), sodium $(12.69 \mathrm{mg})$ and potassium $(410.37 \mathrm{mg})$ was higher than the control sample with $16.35 \mathrm{mg}$ calcium, $9.50 \mathrm{mg}$ iron, $6.13 \mathrm{mg}$ sodium and $242.01 \mathrm{mg}$ potassium. $\beta$ - Carotene content was $12.40 \mu \mathrm{g}$ and $15.30 \mu \mathrm{g}$ for control and the best accepted variation respectively. Vitamin C content of control and best accepted variation were $1.20 \mathrm{mg}$ and $2.33 \mathrm{mg}$ respectively. Statistical analysis for all the nutrients showed significant differences at 5 per cent level.

Mahendran and Nirmala (2014) developed three products viz., dried slices, flour and RTC product using pretreated banana blossom sample of three varieties, Nendran, Rasakadali and Palayankodan. 
Table.1 Nutrient composition of best accepted BBP laddu

\begin{tabular}{|c|c|c|c|c|c|}
\hline $\begin{array}{l}\text { Nutrients } \\
\text { (per } 100 \mathrm{~g} \text { ) }\end{array}$ & Control & $35 \% \mathrm{BBP}$ & F-value & SEm \pm & $\mathrm{CD}$ at $5 \%$ \\
\hline Moisture (\%) & 4.40 & 7.20 & $*$ & 0.25 & 0.98 \\
\hline Protein (g) & 15.23 & 12.68 & $*$ & 0.43 & 1.71 \\
\hline Fat (g) & 9.18 & 11.84 & $*$ & 0.52 & 2.05 \\
\hline Crude fiber (g) & 0.34 & 6.66 & $*$ & 0.39 & 1.54 \\
\hline Carbohydrate (g) & 70.00 & 64.00 & $*$ & 0.38 & 1.49 \\
\hline Energy (kcal) & 423.00 & 413.00 & $*$ & 0.53 & 2.11 \\
\hline $\operatorname{Ash}(\mathbf{g})$ & 0.72 & 4.25 & $*$ & 0.15 & 0.59 \\
\hline \multicolumn{6}{|l|}{ Minerals } \\
\hline Calcium (mg) & 16.35 & 38.62 & $*$ & 0.55 & 2.19 \\
\hline Iron (mg) & 9.50 & 11.63 & $*$ & 0.41 & 1.64 \\
\hline Sodium (mg) & 6.13 & 12.69 & $*$ & 0.59 & 2.34 \\
\hline Potassium (mg) & 242.01 & 410.37 & * & 0.51 & 2.01 \\
\hline \multicolumn{6}{|l|}{ Vitamins } \\
\hline$\beta$ - Carotene $(\mu \mathrm{g})$ & 12.40 & 15.30 & * & 0.56 & 2.23 \\
\hline Vit C (mg) & 1.20 & 2.33 & * & 0.51 & 2.00 \\
\hline
\end{tabular}

*Significant at 5\% level; BBP- banana blossom powder

Table.2 Microbial load of best accepted BBP laddu on storage

\begin{tabular}{|c|c|c|c|}
\hline Laddu & Duration (Days) & $\begin{array}{c}\text { Bacterial } \\
\text { population } \\
\left(\times 10^{3} \mathrm{cfu} / \mathrm{g}\right)\end{array}$ & $\begin{array}{c}\text { Molds } \\
\left.\text { (x } 10^{2} \mathrm{cfu} / \mathrm{g}\right)\end{array}$ \\
\hline \multirow{7}{*}{ Control } & Initial & Nil & Nil \\
\hline & 20 days & Nil & 0.13 \\
\hline & 30 days & 0.43 & 1.9 \\
\hline & 40 days & 1.40 & 2.00 \\
\hline & F-value & $*$ & $*$ \\
\hline & SEm \pm & 0.23 & 0.33 \\
\hline & $\mathrm{CD}$ at $5 \%$ & 0.74 & 1.08 \\
\hline \multirow{7}{*}{$35 \% \mathrm{BBP}$} & Initial & Nil & Nil \\
\hline & 20 days & Nil & Nil \\
\hline & 30 days & 0.3 & 1 \\
\hline & 40 days & 1.3 & 2.2 \\
\hline & F-value & $*$ & $*$ \\
\hline & SEm \pm & 0.06 & 0.24 \\
\hline & $\mathrm{CD}$ at $5 \%$ & 0.21 & 0.80 \\
\hline
\end{tabular}

*Significant at 5\% level; BBP- banana blossom powder 
Fig. 1: Procedure for preparation of BBP laddu

Ghee was melted in a kadai pan, measured amount of bengal gram and green gram flour was added and stirred continuously

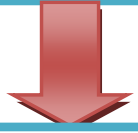

Add banana blossom powder (35\%, $50 \%$ and $65 \%)$, sugar and stir well until a pasty texture is obtained

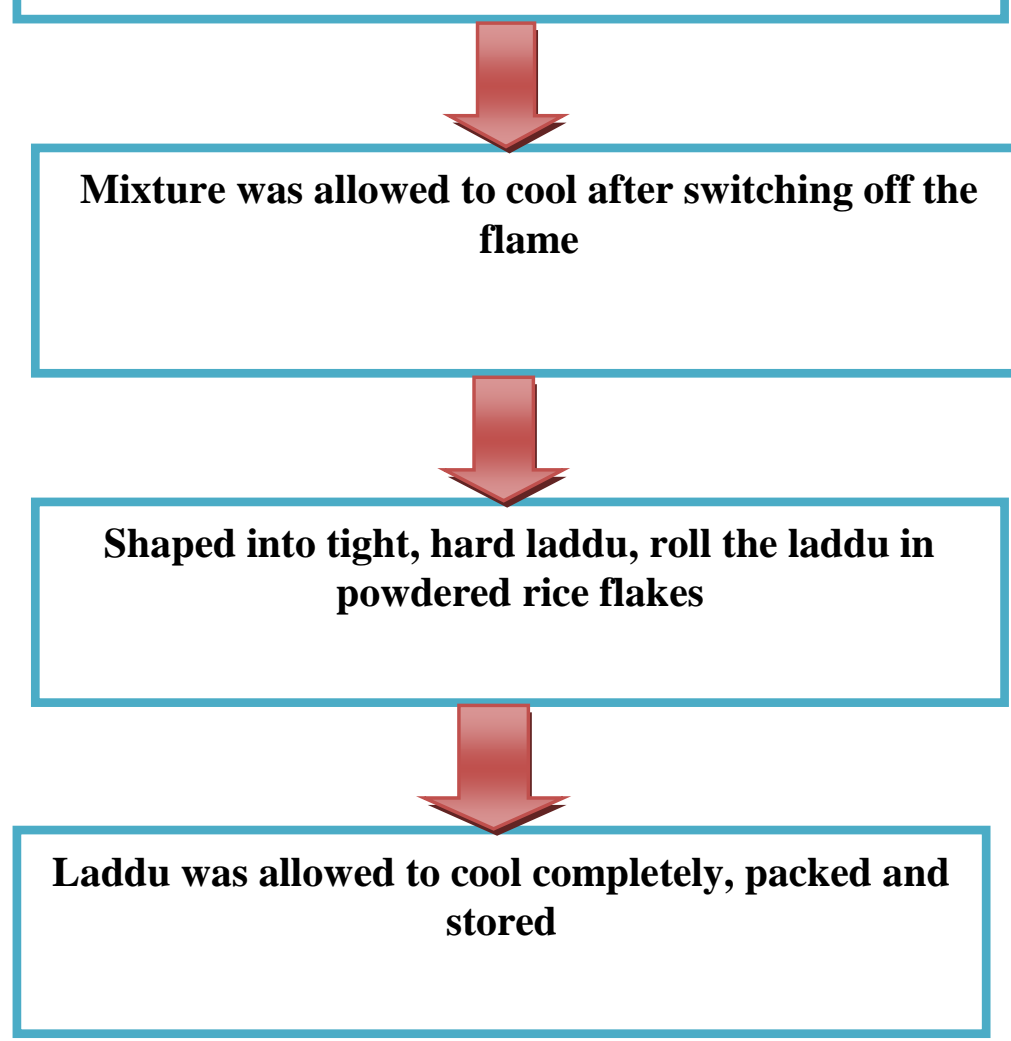




\section{Fig. 2: Mean sensory scores of BBP laddu}

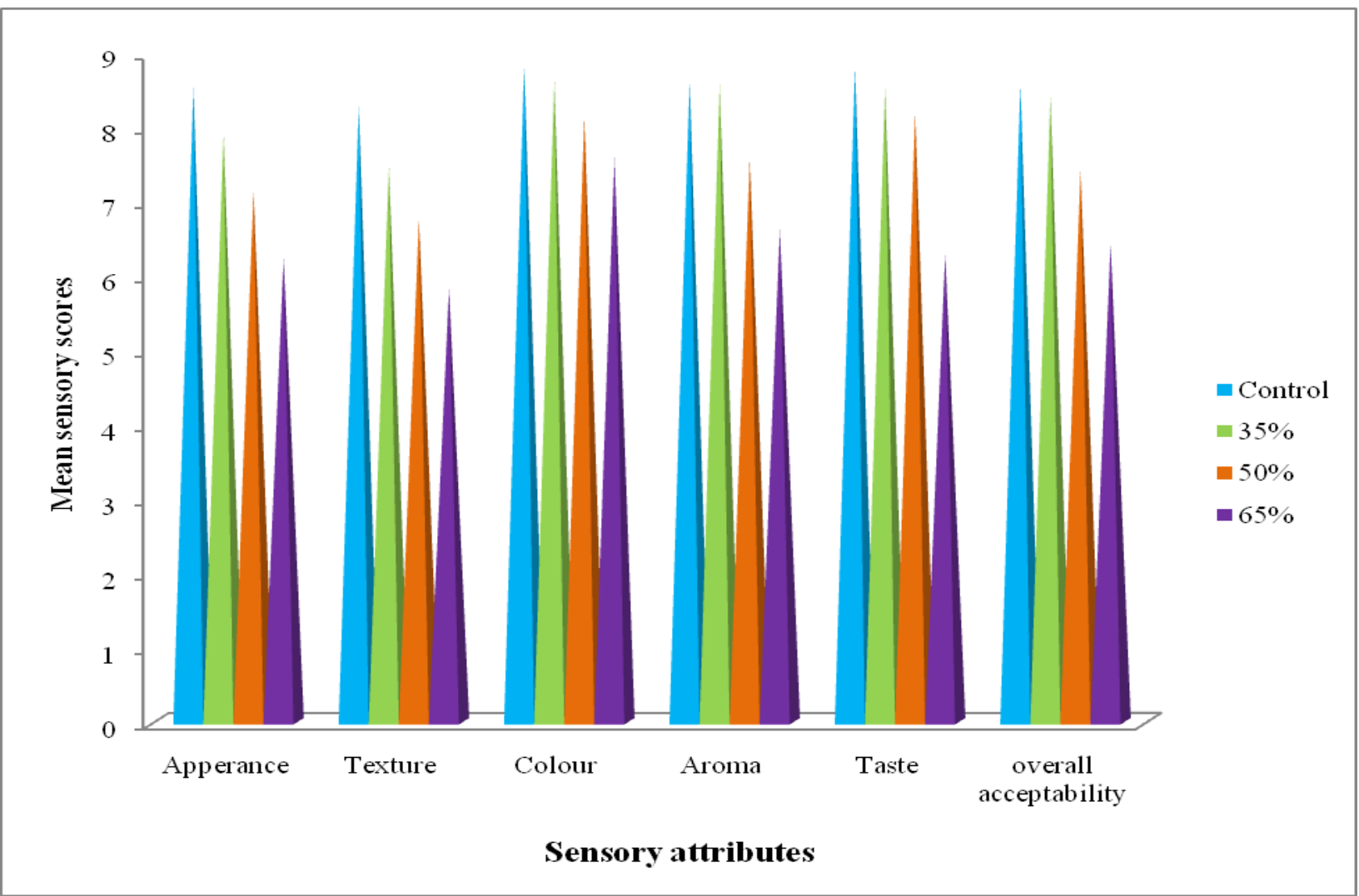

Energy content was found to be the maximum for Nendran RTC product $(288 \mathrm{kcal} / 100 \mathrm{~g})$, protein content was found to be the maximum for Palayankodan RTC product $(18.12 \mathrm{~g} /$ $100 \mathrm{~g}$ ), calcium content was highest for Rasakadali RTC product $(223.33 \mathrm{mg} / 100 \mathrm{~g})$, the maximum sodium content was for Nendran flour $(286.67 \mathrm{mg} / 100 \mathrm{~g})$ and potassium content of Rasakadali RTC product was the highest $(587.63 \mathrm{mg} / 100 \mathrm{~g})$. Variations found in nutrient content may be due to difference of product, processing methods used and mainly due to difference in the cultivar used.

The findings are on par with that recorded by Singh et al., (2013) for $\beta$ - Carotene rich laddu using rice bran, except for $\beta$ - Carotene content. The moisture, energy, protein, fat, carbohydrate, ash, crude fiber, calcium, iron, vitamin $C$ and $\beta$ - Carotene was 4.50 per cent, $470 \mathrm{kcal}, 7.80 \mathrm{~g}, 19.42 \mathrm{~g}, 66 \mathrm{~g}, 1.18 \mathrm{~g}, 1.14 \mathrm{~g}$, $53 \mathrm{mg}, 8.10 \mathrm{mg}, 1 \mathrm{mg}$ and $1894 \mu \mathrm{g}$ respectively.

\section{Shelf life study of the best accepted product Microbial load of BBP laddu on storage}

Microbial population was estimated for total bacteria and mold by standard plate count method and results are presented in Table 2 . The control and the best accepted laddu samples were kept for storage under normal room temperature up to 40 days. Microbial population was checked at initial day, 20, 30 and 40 days. Bacteria were absent in control and 35 per cent BBP incorporated laddu sample on initial day and 20 days of study. Mold was absent on initial day in control 
sample and in 35 per cent BBP incorporated laddu, it was absent during initial and 20 days of the study. Total bacterial population in control were found to be $0.43 \times 10^{3} \mathrm{cfu} / \mathrm{g}$ and $1.4 \times 10^{3} \mathrm{cfu} / \mathrm{g}$ during 30 and 40 days respectively and for the best accepted laddu it was, $0.3 \times 10^{3} \mathrm{cfu} / \mathrm{g}$ and $1.3 \times 10^{3} \mathrm{cfu} / \mathrm{g}$ during 30 and 40 days respectively. Mold populations in the control sample were recorded as $2 \times 10^{2} \mathrm{cfu} / \mathrm{g}$ and that for the best accepted sample, $2.2 \times 10^{2} \mathrm{cfu} / \mathrm{g}$ at the end of 40 days storage study. The increased microbial population at the end of study may be due to increased moisture content. The values obtained were significantly different in both control and 35 per cent BBP incorporated laddu.

Naidu et al., (2013) reported higher values of microbial load with 3.30, 3.90, $4.10 \mathrm{log}$ $10 \mathrm{cfu} / \mathrm{g}$ for total plate count and 2.30, 2.50, 2.90 and $3.00 \log 10 \mathrm{cfu} / \mathrm{g}$ for molds at 0,30 , 60 and 90 days of storage respectively for protein rich multigrain ladoo.

\section{Cost estimation of the best-accepted product}

Cost for the best accepted BBP laddu was calculated taking into consideration the cost of ingredients from local market, and 30 per cent overhead charges. Fifteen per cent profit was added to the production cost. The cost of 100g BBP laddu was Rs. 38.00.

Shelf life of banana fruit is very short, so the underutilized product, blossom which have good nutritional content can be used for value addition of products. The environmental pollution can also be minimized to a certain extent by converting agricultural wastes into value added products.

\section{References}

A.O. A. C., 1980, Official methods of analysis 13th Edn. Association of Official Analytical chemists, Washington, D.C.

Avantina, S., 2006, Textbook of Food science and technology, Narosa publishing house private Limited, New Delhi: 324326.

Mahendran, M. and Nirmala, C., 2014, Nutritional composition of products developed from banana blossom. Int. J. Process. Post Harvest Technol., 5(1): 54-57.

Mohapatra, D., Mishra, S. and Sutar, N., 2010, Banana and its by-product utilisation: an overview. J. Sci. Ind. Res., 69: 323-329.

Naidu, B. G., Shirke, K. J. and Shekhar, A., 2013, A study of a galactogouge and protein rich multi grain ladoo. Int. J.Food Nutr. Sci., 2(2): 91-94.

Ranganna, S., 1996, Hand book of analysis and quality control for fruit and vegetable products. 2nd Ed. Chapter (28) Fruit juices, concentrates and beverages. Tata McGraw-Hill publishing Co., Limited, New Delhi, Pp. 868-925.

Rodriguez-ambriz, S. L., Islas-hernandez, J. J., Agama-acevedo, E., Tovar, J. and Bello-perez, L. A., 2008, Characterization of a fibre-rich powder prepared by liquefaction of unripe banana flour. Food Chem., 107(4): 1515-1521.

Sharmila and Puraikalan, Y. D., 2015, Development and Evaluation of Banana Blossom Incorporated Dark Chocolate. Int. J. Sci. Res., 4(4): 1409-1411.

Singh, 2017, Banana blossom-an understated food with high functional benefits. Int. J. Curr. Res., 9(1): 44156-44519.

Singh, P., Yadav, N., Mishra, P. K., and Sheikh, S., 2013, Utilization of rice bran for the development of value added Indian sweet. Int. J. Agric. Food Sci., 3(2): 76-79. 
Tate, R.L., 1995, Soil Microbiology, John Wiley and Sons, Inc., New York: 228232

Yenagi, N. B., Handigol, J. A., Bala Ravi, S., Mal, B. and Padulosi, S., 2010. Nutritional and technological advancements in the promotion of ethnic and novel foods using the genetic diversity of minor millets in India. Indian Journal of Plant Genetic Resources, 23(1), 82.

\section{How to cite this article:}

Fathima Zehla, P., D. Vijayalakshmi, V.C. Suvarna and Shilpa Yatnatti 2018. Processing of Banana Blossom and its Application in Food Product. Int.J.Curr.Microbiol.App.Sci. 7(08): 1243-1250. doi: https://doi.org/10.20546/ijcmas.2018.708.140 